\title{
Ovarian development and the reproductive profile of Astyanax altiparanae (Teleostei, Characidae) over one year: Applications in fish farming
}

\author{
Mônica Cassel ${ }^{\text {a, * }}$, Chayrra Chehade ${ }^{\text {a }}$, Giovana Souza Branco ${ }^{\mathrm{a}, 1}$, Danilo Caneppele ${ }^{\mathrm{b}}$, \\ Elizabeth Romagosa ${ }^{c}$, Maria Inês Borella ${ }^{\text {a }}$ \\ ${ }^{a}$ Fish Endocrinology Laboratory, Department of Cell and Developmental Biology, Institute of Biomedical Sciences, University of Sao Paulo, Av. Prof Lineu \\ Prestes n. 1524, lab 426, CEP 05508-000, Sao Paulo, SP, Brazil \\ ${ }^{\mathrm{b}}$ Hydrobiology and Aquaculture Station, Sao Paulo Energy Company (CESP), Rod. Tamoios n. 21500, CEP 12260-000, Paraibuna, SP, Brazil \\ ${ }^{\mathrm{c}}$ Fishery Institute, APTA, SAA, Av. Francisco Matarazzo n.455, CEP 05031-900, Sao Paulo, SP, Brazil
}

\section{A R T I C L E I N F O}

\section{Article history:}

Received 26 July 2016

Received in revised form 4 April 2017

Accepted 27 April 2017

Available online 28 April 2017

\section{Keywords:}

Fish production

Germ cell proliferation

Histology

Reproductive management

Reproductive migration

Ultrastructure

\begin{abstract}
A B S T R A C T
Astyanax altiparanae is a Brazilian species of substantial commercial, environmental and scientific importance; however, existing studies on its reproduction do not seem to provide enough details. In light of the increasing use of this species in fish farming and the need for basic studies for the development of new production technologies, we describe the structural and ultrastructural characteristics of the ovaries of $A$. altiparanae, and characterize the species' reproductive cycle. Females were collected monthly from March 2013 to February 2014, and reproductive management began in October 2013. The ovaries were removed, fixed in Karnovsky's fixative, and prepared for light microscopy, transmission electron microscopy and immunohistochemistry anti-PCNA. These techniques enabled us to characterize the ovaries, the germ cells, and the somatic cells in detail, as well as their changes over time. The reproductive cycle was characterized based on the monthly variation in the gonadosomatic ratio, the proportion of germ cells, and the rate of oogonium proliferation. The macroscopic analysis of the ovaries suggests that the vascularization pattern and color of the ovaries vary according to development. There are new types of analyses that can be applied even in the fish farming industry, such as a comparison between ovaries staining and weight or the frequency distribution of these colors throughout the year. This study also provides details on microscopic characteristics that have never before been reported for species of Astyanax, such as the presence of annulate lamellae in oogonia, the development of the zona pellucida from oocytes in the one-nucleolus step, and the development of the micropylar apparatus in oocytes in the cortical alveolar step. When the reproductive cycle was analyzed, this species was found to have a long period of spawning, with a reproductive peak from October to February and multiple spawning events, confirming the period already described in the literature. Variations in reproductive periods and the ability to reproduce in lentic environments suggest that $A$. altiparanae has the ability to respond quickly to environmental changes and exhibits high reproductive flexibility. All of these characteristics confirm the great potential of this species in the fish farming industry.
\end{abstract}

(c) 2017 Elsevier Inc. All rights reserved.

\section{Introduction}

Knowledge on the reproductive characteristics of fish is crucial

\footnotetext{
* Corresponding author.

E-mail addresses: monica_cassel@usp.br, cassel.mcp@gmail.com (M. Cassel).

1 Current address: Department of Morphology, Biosciences Institute, UNESP Botucatu, District of Rubião Junior s/n, CEP 18618-000, Botucatu, SP, Brazil.
}

for understanding the adaptations developed by species to maximize reproductive success in a given environment [1]. Studies on the reproductive biology of fish may take different approaches, focusing, for example, on the understanding of gonadal development or the reproductive cycle of the species. Gonadal development can be analyzed macroscopically based on the changes in shape, size, color, and texture of the gonads [2,3]. However, an analysis of microscopic characteristics enables a more precise and detailed description of the morphological and structural changes 
that occur during this process [4,5]. In females, an understanding of the morphology of the oocytes is important for understanding the dynamics of oogenesis specifically and the reproductive cycle more generally [6].

Reproductive cycles encompass the gonadal development necessary for adult fish to spawn at the appropriate time; they also include the removal of residual oocytes through atresia and regeneration of the germinal epithelium for the next spawning season [7]. An understanding of gonadal development on different time scales and the interactions between these scales can improve our understanding of fish reproduction [7]. Investigations into the reproductive cycle of a given species can also help to define different phases of gonadal development, as well as the triggers that initiate the process of cell proliferation and differentiation in the formation of gametes [3].

Cell proliferation is a highly regulated process that is known to be essential for maintaining ovarian homeostasis [8]. In contrast to mammals, oogonia continue to proliferate in adult female fish [9], so the stores of young oocytes and follicles are renewed $[10,11]$. The pre-follicular and follicular cells begin to proliferate during folliculogenesis to support oocyte growth [12]. However, mitosis of oogonia in fish has been found to be more intense at the end of each reproductive cycle [8], when the ovarian tissues are reorganized [13]. This characteristic marks the start of a new cycle.

During the reproductive cycle, oocyte growth begins and changes in various ways that contribute to the reproductive success of the species [1]. In this regard, the order Characiformes represents a group of very important species for studies on reproductive success and to the involvement of reproduction strategies in fish farming: most of the species of this order need to perform reproductive migration and spawning tends not to occur when they are confined, despite females' normal oocyte development [14].

The order Characiformes contains at least 24 families, about 520 genera, and about 2300 species [15]. It addition to its ecological and academic importance, the order is of substantial commercial importance as a food, particularly in the case of the species of the genus Astyanax [16]. The genus Astyanax is comprised of freshwater fish that are widely distributed in the Neotropical region. Of the species that comprise this genus, Astyanax altiparanae [17] has become an attractive commercial fish for fish farmers because of the ease of fish-seed production, the species' fast growth and resistance, and the simple handling required for this species [18]. Thus, this study aims to: (1) describe the structural and ultrastructural characteristics of the ovaries of A. altiparanae; (2) characterize the reproductive cycle of this species in captivity; and (3) relate these characteristics to the existing requirements for the production and management of this species in fish farming.

\section{Materials and methods}

\subsection{Specimen maintenance and reproductive management}

Sampling was performed from March 2013 to February 2014 at the Hydrobiology and Aquaculture Station of the São Paulo Energy Company in Paraibuna (CESP Paraibuna), São Paulo, Brazil $\left(23^{\circ} 24^{\prime} 51^{\prime \prime} \mathrm{S}, 45^{\circ} 35^{\prime} 59^{\prime \prime} \mathrm{W}\right)$. The specimens used were from a batch produced in a reproductive management scheme performed by the CESP. The specimens were one year of age, with standard lengths ranging from $7.6 \mathrm{~cm}$ to $11.7 \mathrm{~cm}(9.94 \pm 0.49)$ and with total weights ranging from $12.94 \mathrm{~g}$ to $49.87 \mathrm{~g}(30.15 \pm 4.73)$. The voucher specimens were deposited at the Museum of Zoology of the University of São Paulo (MZUSP 113746).

Both male and female specimens were kept in a $200 \mathrm{~m}^{3}$ cement $\operatorname{tank}(20 \times 10 \times 1 \mathrm{~m})$ at a density of $10-15 \mathrm{fish} / \mathrm{m}^{3}$ or $\approx 500 \mathrm{~g} / \mathrm{m}^{3}$ with natural light and were fed commercial food twice a day (Nutripiscis, 32\% C.P.) from March to September 2013. The water in the tank was replaced constantly with water from the Paraibuna Dam. The dam water qualities were measured at two points bimonthly during the collection period. The average water quality parameters in the tank were as follows: electric conductivity $=30.07 \pm 2.91 \mu \mathrm{S} / \mathrm{cm}$; dissolved oxygen $=$ $6.80 \pm 1.12 \mathrm{mg} / \mathrm{L} ; \quad \mathrm{pH}=7.11 \pm 0.40 ;$ water temperature $=22.93 \pm 3.28{ }^{\circ} \mathrm{C}$; turbidity $=4.56 \pm 1.52 \mathrm{NTU}$. The detailed data are presented in Table 1 . Fifteen females from this tank were sampled each month.

During the reproductive period of the species, which is believed to occur from October to February [19], batches of breeders were selected. These batches were divided into three tanks of $10 \mathrm{~m}^{3}$ $(2 \times 5 \times 1 \mathrm{~m})$ : two tanks with female specimens $(n=120$ each $)$ and one tank with males $(n=200)$. The classification of male and female individuals was based on their sexual dimorphism, as males possess hooks on the anal fin [17]. The specimens in these tanks received the same water supply (i.e. water from the dam itself) and the same feeding regime as those in the $200 \mathrm{~m}^{3}$ tank.

Reproductive management was implemented once per month, and only one tank with females was used. The other female tank served as a control group in which no reproductive management practices were performed at any time during the collection periods. The reproductive management practice used in this study has been briefly described by Chehade et al. [20]; however, the exact method used herein was as follows:

The specimens used in the reproduction management scheme were transferred to the laboratory at a rate of two males for each female. There, they were placed in one aquarium of $1 \mathrm{~m}^{3}$ filled to $40 \%$ of its volume. In this aquarium, individuals were kept for a minimum of $20 \mathrm{~h}$ without feeding, with constant water renewal

Table 1

Qualities of the dam water that supplies the tanks of the Aquaculture Sector of São Paulo Energy Company (CESP) of Paraibuna, São Paulo, Brazil.

\begin{tabular}{|c|c|c|c|c|c|c|c|c|}
\hline \multirow[t]{2}{*}{ Characteristic } & \multirow[t]{2}{*}{ Collection Point } & \multicolumn{7}{|c|}{ Date of Collection } \\
\hline & & Feb. 2013 & Apr. 2013 & Jun. 2013 & Aug. 2013 & Oct. 2013 & Dec. 2013 & Feb. 2014 \\
\hline \multirow[t]{2}{*}{ Conductivity $(\mu \mathrm{S} / \mathrm{cm})$} & IUNA 00850 & 34.00 & 33.00 & 34.00 & 33.00 & 33.00 & 31.00 & 32.00 \\
\hline & IUNA 00950 & 27.00 & 28.00 & 26.00 & 28.00 & 27.00 & 27.00 & 28.00 \\
\hline \multirow[t]{2}{*}{ Dissolved oxygen $(\mathrm{mg} / \mathrm{L})$} & IUNA 00850 & 7.50 & 6.70 & 7.10 & 7.30 & 8.40 & 7.30 & 4.50 \\
\hline & IUNA 00950 & 7.40 & 6.80 & 6.80 & 6.20 & 7.70 & 7.30 & 4.20 \\
\hline \multirow[t]{2}{*}{$\mathrm{pH}$} & IUNA 00850 & 7.60 & 7.40 & 6.50 & 6.80 & 6.70 & 6.70 & 7.70 \\
\hline & IUNA 00950 & 7.20 & 7.30 & 6.60 & 7.00 & 7.40 & 6.90 & 7.70 \\
\hline \multirow[t]{2}{*}{ Water temperature $\left({ }^{\circ} \mathrm{C}\right)$} & IUNA 00850 & 26.00 & 22.00 & 19.00 & 18.00 & 22.00 & 26.00 & 28.00 \\
\hline & IUNA 00950 & 26.00 & 22.00 & 20.00 & 18.00 & 22.00 & 25.00 & 27.00 \\
\hline \multirow[t]{2}{*}{ Turbidity (NTU) } & IUNA 00850 & 7.00 & 7.00 & 4.00 & 3.00 & 3.00 & 5.00 & 6.30 \\
\hline & IUNA 00950 & 4.00 & 5.90 & 3.00 & 6.00 & 3.00 & 3.00 & 3.70 \\
\hline
\end{tabular}

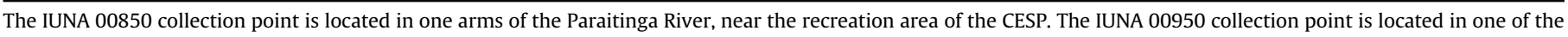
arms of the Paraibuna River at the junction where the arms of the Paraibuna River and the Sierra River meet. 
(approximately $10 \mathrm{~L} / \mathrm{min}$ ) and with the input approximately $1 \mathrm{~m}$ away from the surface of the water. The average water quality parameters in the aquarium during the reproductive management process were as follows: electric conductivity $=37.80 \pm 2.40 \mu \mathrm{S} / \mathrm{cm}$; dissolved oxygen $=6.46 \pm 0.20 \mathrm{mg} / \mathrm{L} ; \mathrm{pH}=6.88 \pm 0.25$; water temperature $=23.50 \pm 1.14{ }^{\circ} \mathrm{C}$. These conditions culminated in semi-natural spawning in the aquarium.

The sample size was 15 control females and 15 females involved in the reproductive management practices. Males were not analyzed further in this study. The female groups were kept separate for sampling in February 2014 to determine the ovaries recovery process. In this month, no reproductive management schemes were implemented.

\subsection{Collection and macroscopic analysis of the ovaries}

Before the dissection procedures, all of the animals were euthanized with an overdose of an anesthetic ( $0.1 \%$ aqueous solution of benzocaine) until the cessation of opercular beats, in accordance with the procedure approved by the Ethics Committee on Animal Experiments of the Institute of Biomedical Sciences (ICB) of the University of São Paulo (USP), \#2013/022. Specimens were photographed, and the standard lengths and total weight values were measured in centimeters and grams, respectively.

Both ovaries from each female were dissected, photographed, measured, and weighed separately. The macroscopic morphological characterization of the ovaries was established based on weight, length, color, and the monthly variations in these features. The measurements also included the gonadosomatic ratio (GSR) of all females, which is the percentage that the ovaries represent of the fish's total weight according to the equation established by Vazzoler [3]: GSR $=(\mathrm{Wo} / \mathrm{Wt}) \times 100$. In this equation, Wo is the weight of the ovaries (because the ovaries were weighed separately, the individual ovaries' weights were added together, and the total value was used in this formula), and Wt is the total weight of the specimen. The variations in the GSR were compared between the months to help characterize the reproductive cycle of the species. After the macroscopic study, the ovaries were fixed in Karnovsky's fixative (2\% glutaraldehyde and $4 \%$ paraformaldehyde in Sorensen buffer [0.1 M, pH 7.2]) or in $4 \%$ paraformaldehyde in sodium phosphate buffer [0.1 M, pH 7.4].

\subsection{Morphological and ultrastructural analysis of the ovaries}

The ovaries samples fixed in Karnovsky's fixative were fragmented, and some of the fragments were washed in water and dehydrated in increasing concentrations of ethanol. The material was then added to a glycol methacrylate resin (Historesin, Leica) for infiltration and inclusion. The blocks were cut to $3 \mu \mathrm{m}$ in thickness with $300 \mu \mathrm{m}$ of distance between each one in order to prevent the observation of the same structures in consecutive sections. The sections were stained with periodic acid - Schiff's reactive + iron hematoxylin + metanil yellow [21]. The slides were examined and documented in photos using an Axioskop 2 light microscope (Zeiss Inc., USA) coupled with an AxioCam MRC5 camera (Zeiss Inc., USA) and equipped with a ZEN 2012 digital image capture device.

Other fragments of the ovaries fixed in Karnovsky's fixative were prepared for transmission electron microscopy and for ultrastructural analysis. The fragments were postfixed in $1 \%$ osmium tetroxide in a Sorensen buffer $(0.1 \mathrm{M}, \mathrm{pH} 7.2)$, counterstained with $5 \%$ uranyl in water, dehydrated in acetone, and embedded in Epon resin. After the selection of areas of interest in the semi-thin sections, the samples were sectioned with an ultramicrotome equipped with a diamond knife, and then stained with saturated uranyl acetate in $50 \%$ ethanol and lead citrate. Finally, the sections were documented in photos using a Jeol 1010 transmission electron microscope (Jeol Inc., Japan) equipped with a Gatan digital image capture device and with an Orius SC1000 camera attached (Gatan Inc., USA).

For the analysis of the microscopic characteristics, the germinal and somatic cell types and their characteristics were identified and described based on staining affinities, as proposed by Grier [22]. In addition, the major length axis of the cell (CL) and the nucleus (NL) were measured in 50 cells per stage of development, and the average value and standard deviation were calculated in micrometers. Transmission electron microscopy was used for greater structural detailing of the cell types.

\subsection{Analysis of the reproductive cycle}

To establish the phases of the reproductive cycle, the germ cells were analyzed quantitatively based on the monthly calculation of the ratio of cell stages, as detailed by Quagio-Grassiotto et al. [12]. For the germ cell count, all of the cells were counted in the six sections prepared previously for morphological analysis, so there were six sections per specimen for all specimens and all months. The nomenclature adopted to describe the reproductive cycle is based on Brown-Peterson et al. [23].

Furthermore, the monthly proportion of immunostained oogonia was compared using an immunoperoxidase antibody assay for cell proliferation in order to determine the repopulation period of the ovaries. In this immunoperoxidase technique, all of the oogonia in four sections (per individual) were counted; five individuals per month were randomly selected. For the months in which reproduction management was applied, five individuals from each group were selected.

To the immunoperoxidase assay, ovaries fragments were fixed in $4 \%$ paraformaldehyde. These fragments were washed, dehydrated in increasing concentrations of ethanol, diaphanized in xylene, and embedded in Paraplast. The blocks were cut to $5 \mu \mathrm{m}$ thick with $300 \mu \mathrm{m}$ of distance between each one. Then, sections were deparaffinized in xylene, hydrated in ethanol series, washed in running water, and Tris-buffered saline with 0.05\% Tween-20 (TBS-T pH 7.2). Antigen retrieval was performed in a citrate buffer at $\mathrm{pH} 6.0$ for $20 \mathrm{~min}$ at $90^{\circ} \mathrm{C}$, cooled in the same solution for $10 \mathrm{~min}$, and then washed in TBS-T. To block endogenous peroxidase and nonspecific sites, Hydrogen peroxidase block and Protein block solutions [Kit Spring Reveal - Polyvalent Free Biotin-DAB (SPD125)] were used, respectively. The blocks were applied for two hours each.

The slides were then incubated overnight in a humid chamber at $4{ }^{\circ} \mathrm{C}$ using the primary antibody Anti-PCNA $(1: 10,000)$ [clone PC10: ab29, Abcam Inc.]. After incubation, slides were washed in TBS-T and treated as stated in the Spring REVEAL kit datasheet [Complement + Conjugate]. The sections were washed again in TBS-T and revealed with 3-3' diaminobenzidine (DAB). The sections were then counterstained with Mayer's hematoxylin, differentiated with lithium carbonate, and washed under running water. Finally, the material was dehydrated, mounted, and analyzed using a light microscope (Axioskop 2, Zeiss Inc., USA). The primary antibody was omitted in some sections for the negative control.

\subsection{Statistical analysis}

All of the quantitative results obtained were tested for normal distribution using the Lilliefors test. ANOVA analysis followed by Student's $t$-test were used for data with normal distribution. For the data with non-normal distribution, Kruskal-Wallis test was applied, followed by paired distribution analysis with the Wilcoxon test. The tests were performed in Systat 10, and the significance value was 
set at $\mathrm{P} \leq 0.05$.

\section{Results}

\subsection{Macroscopic characteristics of the ovaries}

The ovaries are paired, ovoid, and highly vascularized organs located in the coelomic cavity. There was no difference in the macroscopic development of the ovaries between groups with and without reproductive management. However, the color appeared to vary according to the size and weight of the ovaries, and all three characteristics seemed to change as the ovaries developed. At first, ovaries were brownish and moderate in size (Table 2). As they developed, the ovaries became more grayish and considerably larger than the others; after the spawning process, the ovaries became remarkably reddish and smaller (Table 2; Fig. 1A).

Size and weight data (Table 2) were found to corroborate the definitions of the groups above. The analysis of variance of the color of the ovaries relative to their weight confirmed the separation by this criterion $(\mathrm{H}=102.631 ; \mathrm{P}<0.001)$. Therefore, brownish, grayish, and reddish ovaries represent different weight groups $(\mathrm{P}<0.001$; Fig. 1C). Furthermore, the ordination of ovarian development based on color may be correlated with the frequency plot (Fig. 1B). This graph shows that: (1) brownish ovaries were more frequently present from March to August 2013; (2) there was a peak of grayish ovaries in September 2013, shortly before the beginning the reproductive management process, and there were also alternating peaks for specimens that were not managed; (3) the peaks of grayish ovaries are alternated with peaks of the reddish ovaries from specimens that were included in the reproductive management practice and therefore spawned; (4) finally, both groups exhibit a final peak of grayish ovaries; these groups were kept separate, but reproductive management techniques were not applied to either group.

\subsection{Microscopic and ultrastructural characteristics of the ovaries}

Because there were no differences in the microscopic characteristics of the ovaries between groups with and without reproductive management, the description of cell types is presented according to their development. The ovaries are classified as cystovarian, i.e. the enclosed cavity presents a germinal compartment in the form of lamellae that protrude toward the lumen (Fig. 2A). Bordering the ovigerous lamellae and outlining the ovarian lumen, the germinal epithelium contains two cell types: germ cells and somatic cells (Fig. 2B). The oogonia $(\mathrm{CL}=11.6 \pm 2.3 \mu \mathrm{m}$; $\mathrm{NL}=7.2 \pm 1.6 \mu \mathrm{m}$ ) are the first germ cells of the oogenic lineage and may be found alone or in nests as mitotic divisions occur (Fig. 2C). They are characterized by having a spherical nucleus, one or two nucleoli, and an acidophilic cytoplasm (Fig. 2C). In electron microscopy, these cells are more electron-lucid than the other germ cells, and their cytoplasm has abundant mitochondria, several nuages close to the nuclear membrane, a prominent Golgi complex, and annulate lamellae (Fig. 2D).

The formation of the nests reveals the association of pre- follicular cells, which accompany the oogonia in its development (Fig. 2C-D). In these nests, some cells can remain undifferentiated or may commit to folliculogenesis, thus beginning the process of meiosis and giving rise to the initial oocytes (Fig. 2C).

The oocyte begins its primary growth and is in the onenucleolus step $(\mathrm{CL}=19.3 \pm 4.7 \mu \mathrm{m} ; \mathrm{NL}=10.5 \pm 3.5 \mu \mathrm{m})$. At this step, they present a spherical nucleus and a basophilic cytoplasm (Fig. 2E). From that moment on, the nucleus is referred to as germinal vesicle, and the surrounding cells are now considered follicular cells. These cells, along with the oocyte, constitute the initial ovarian follicle that remains connected to the germinal epithelium (Fig. 2E-F). In electron microscopy, the oocyte presents a cytoplasm with groups of mitochondria and nuages scattered near the germinal vesicle (Fig. 2G). There is also the beginning of the development of small microvilli, which extend from the oocyte toward the follicular cells, which themselves have a thin nucleus and cytoplasm (Fig. 2H).

The next step of development is characterized by the appearance of multiple nucleoli centered in the germinal vesicle $(\mathrm{CL}=67.7 \pm 21.1 \mu \mathrm{m} ; \mathrm{NL}=27.2 \pm 9.1 \mu \mathrm{m})$, a highly basophilic cytoplasm, and a germinal vesicle with a regular contour (Fig. $3 \mathrm{~A}$ ). This step is soon replaced by the next one, in which several nucleoli move to the periphery of the germinal vesicle and characterize the perinucleolar oocytes $(\mathrm{CL}=139.5 \pm 40.3 \mu \mathrm{m}$; $\mathrm{NL}=59.4 \pm 21.3 \mu \mathrm{m}$; Fig. 3B). At this step, the germinal vesicle begins to exhibit an irregular border, and several nuages and Balbiani corpuscles appear (Fig. 3B-D). The nuages appear as less intense staining areas in the cytoplasm and are granular and highly electron-dense in electron microscopy, normally associated with mitochondria (Fig. 3B-C). The Balbiani corpuscles appear as less electron-dense areas associated with mitochondria and a rough endoplasmic reticulum (Fig. 3D).

The perinucleolar step also encompasses the start of zona pellucida development (Fig. 3B). Thus, microvilli development from the oocyte toward the follicular cells is noted, though the latter do not have these extensions (Fig. 3E). A combination of a new layer of somatic cells known as the theca cell layer surrounds the oocyte (Fig. 3B and F) above the basal membrane synthesized by the follicular cells. Because they are associated with developing oocytes, these new cells have a plasma membrane with many vesicles (Fig. 3F).

Next, the oocyte passes into the cortical alveolar step $(\mathrm{CL}=246.6 \pm 44.0 \mu \mathrm{m} ; \mathrm{NL}=98.6 \pm 27.5 \mu \mathrm{m})$, in which the germinal vesicle has a more irregular contour; the alveoli and a more substantial zona pellucida appear on the periphery of the oocyte (Fig. 4A). The latter begins to show distinct layers of microvilli, a more numerous and developed layer starting from the oocyte, and another shorter layer starting from the follicular cells that is already in contact with the oocyte microvilli (Fig. 4B-C). The oocyte surface also exhibits characteristics of this step with numerous vesicles for the incorporation of substances by the oocyte from the follicular cells (Fig. 4C-D). The cortical alveoli are found bordering the oocyte surface, where they become progressively more numerous and constitute multiple vesicles; they often have lamellar bodies inside (Fig. 4A and D-E). Moreover, the cytoplasm starts to present several

Table 2

Average weight and size $( \pm \mathrm{SD})$ of Astyanax altiparanae ovaries grouped by ovary color.

\begin{tabular}{|c|c|c|c|c|c|c|}
\hline \multirow[t]{2}{*}{ Color } & \multicolumn{3}{|l|}{ Left Ovary } & \multicolumn{3}{|l|}{ Right Ovary } \\
\hline & Weight & Length & Width & Weight & Length & Width \\
\hline Brownish & $2.02( \pm 1.14)$ & $2.89( \pm 0.65)$ & $1.76( \pm 0.57)$ & $2.13( \pm 1.10)$ & $3.02( \pm 0.66)$ & $1.83( \pm 0.59)$ \\
\hline Grayish & $2.90( \pm 1.05)$ & $3.38( \pm 0.49)$ & $2.20( \pm 0.38)$ & $3.08( \pm 1.16)$ & $3.54( \pm 0.54)$ & $2.27( \pm 0.46)$ \\
\hline Reddish & $0.51( \pm 0.13)$ & $1.78( \pm 0.29)$ & $1.13( \pm 0.21)$ & $0.55( \pm 0.12)$ & $2.01( \pm 0.34)$ & $1.14( \pm 0.14)$ \\
\hline
\end{tabular}


(A)
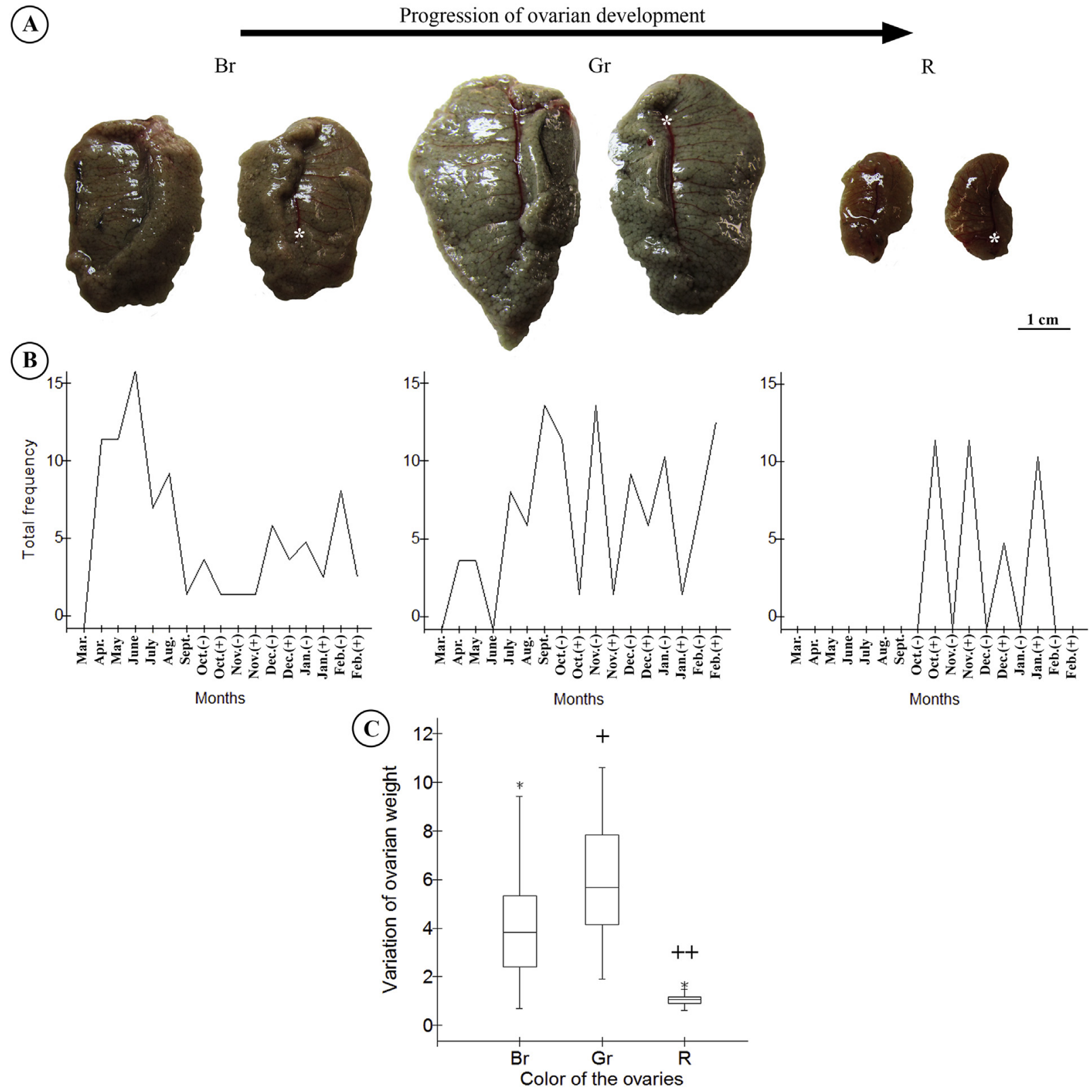

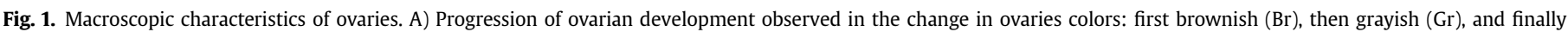

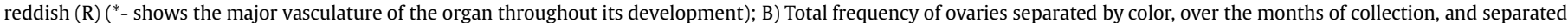

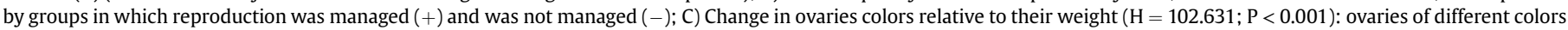
form different weight groups $(+,++, \mathrm{P}<0.001)$.

mitochondria, Golgi complexes, and a rough endoplasmic reticulum (Fig. 4B and D-E).

This step also includes the onset of a small opening in the oocyte known as micropylar apparatus (Fig. $4 \mathrm{~A}$ and $\mathrm{F}$ ), whereby the spermatozoa can penetrate the oocyte. The zona pellucida is found to have a concave region that tapers towards the plasma membrane. There is also a highly specialized and hypertrophied cell in the follicular cell layer covering this concavity known as micropylar cell, which seals the micropylar pore or channel. These features mark the final step of primary growth.

The oocyte starts secondary growth with a further increase in volume due to the incorporation of yolk which, in principle, is seen as small spherical vesicles scattered below the cortical alveoli $(\mathrm{CL}=335.7 \pm 34.9 \mu \mathrm{m} ; \mathrm{NL}=124.9 \pm 26.7 \mu \mathrm{m}$; Fig. 5A $)$. The germinal vesicle has a highly irregular contour (Fig. 5A), and the zona pellucida becomes thicker as the microvilli of the oocyte and follicular cells elongate (Fig. 5B). Oocytes in the late secondary growth step $(\mathrm{CL}=460.0 \pm 66.6 \mu \mathrm{m} ; \mathrm{NL}=148.8 \pm 26.8 \mu \mathrm{m})$ have yolk vesicles with a maximum diameter, although there are vesicles of different sizes (Fig. 5C-D). Finally, when the oocyte is in the full-grown step $(\mathrm{CL}=643.5 \pm 133.0 \mu \mathrm{m} ; \mathrm{NL}=157.9 \pm 41.6 \mu \mathrm{m})$, yolk vesicles fill the entire cytoplasm (Fig. 5E), the zona pellucida is fully developed (Fig. 5F), and the micropylar apparatus has been completely formed (Fig. 5G).

In the oocyte maturation step, the germinal vesicle breaks down and there is the coalescence of the yolk vesicles $(\mathrm{CL}=685.0 \pm 117.1 \mu \mathrm{m}$; Fig. $6 \mathrm{~A})$. At ovulation, the follicular cell layer, the basal membrane, and the theca cell layer are broken down 

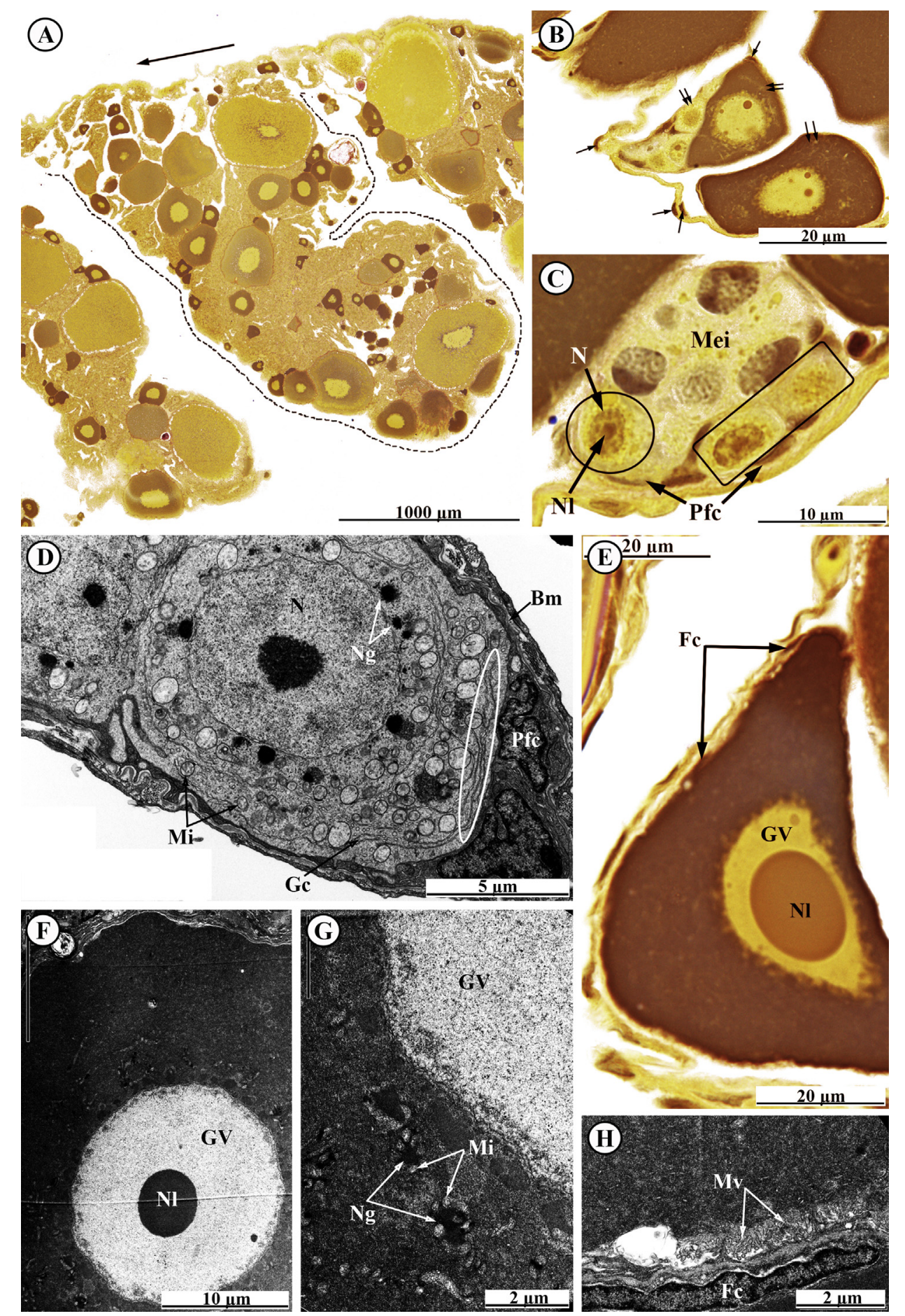

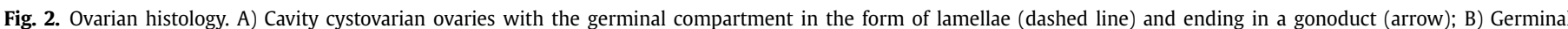

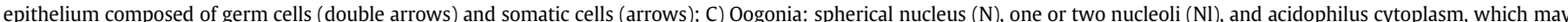

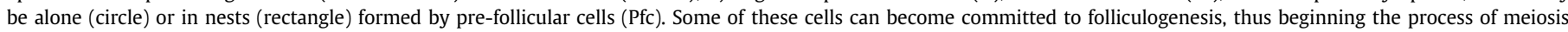

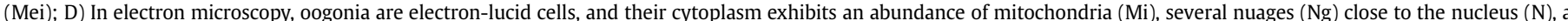

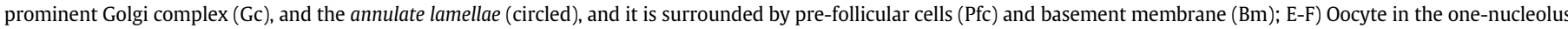

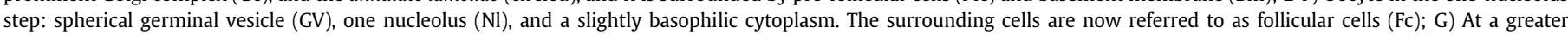

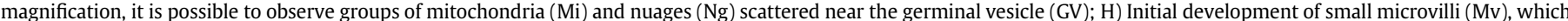

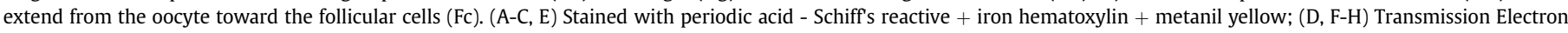
Microscopy.

as an opening through which the oocyte moves toward the ovarian lumen (Fig. 6B). The cell layers remaining after the release of the oocyte form the post-ovulatory complex. The post-ovulatory complex (Fig. 6C-D) involutes gradually to form a massive cluster and, in the process, specific and progressive features appear, such as columnar follicular cells with a peripheral nucleus and many 
vacuoles, the accumulation of a yellow-brown pigment, increased vascularity in the theca cell layer, and fragmentation of the basal membrane. The atretic oocytes (Fig. 6E-F) also undergo degeneration and resorption, the characteristics of which include the rupture of the nuclear envelope, the splitting of the zona pellucida, an overflow of the yolk, columnar follicular cells with phagocytic characteristics, increased vascularity of the theca cell layer, and progressive reduction in oocyte volume.

These tissue restructuring processes seem to involve several granulocytes from the blood capillaries (Fig. 7A). These granulocytes are present throughout the reproductive cycle and are close to capillaries and connective tissue (Fig. 7B) as well as near the oocyte (Fig. 7C). Apart from the capillaries, a set of large vessels is found to be associated (artery + vein + lymphatic vessels), and

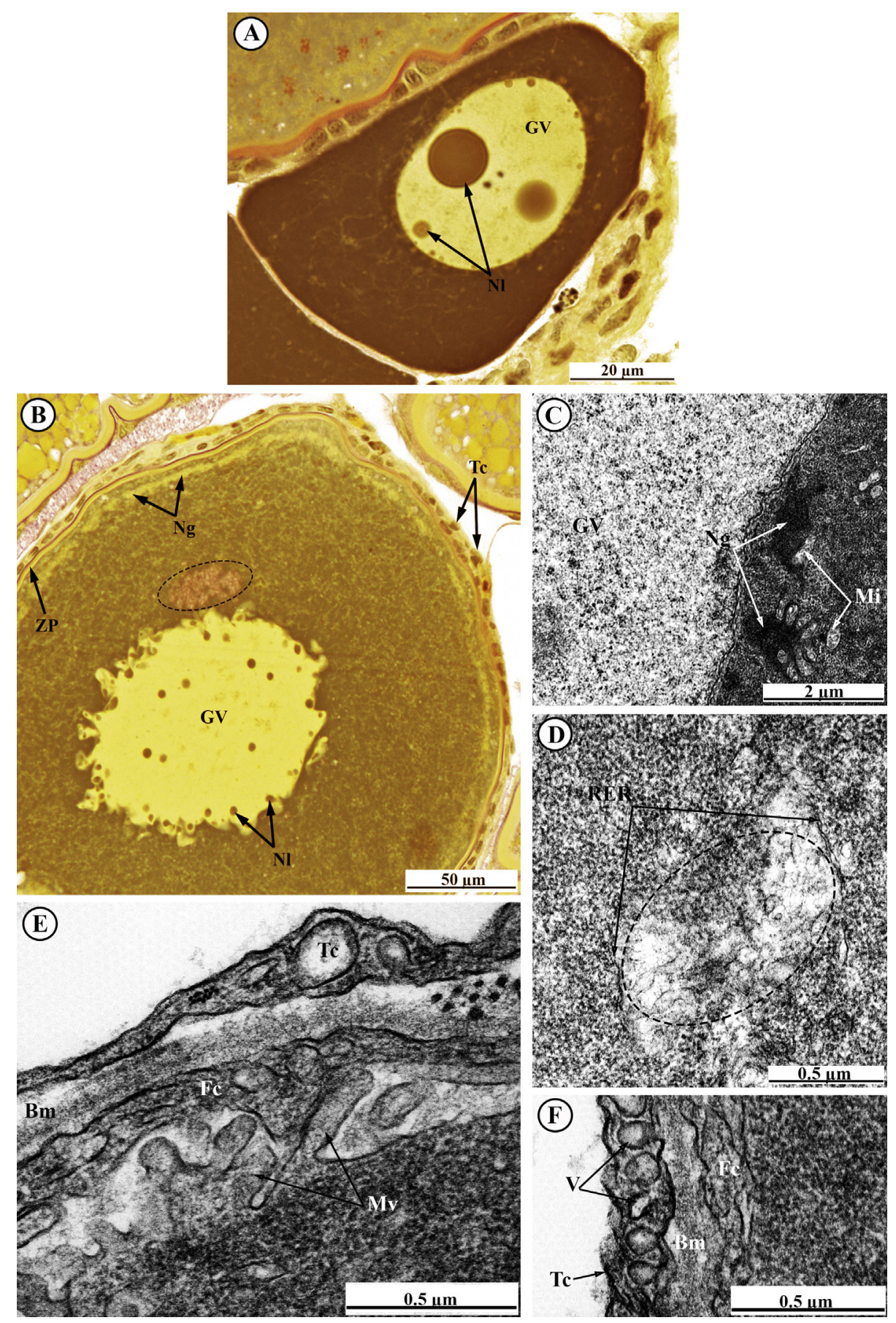

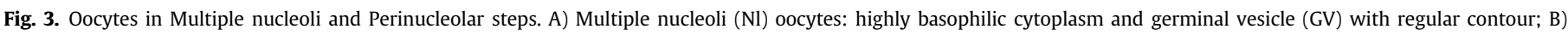

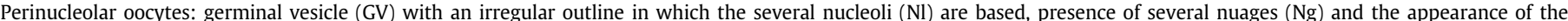

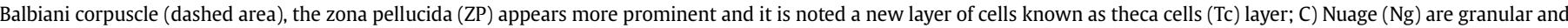

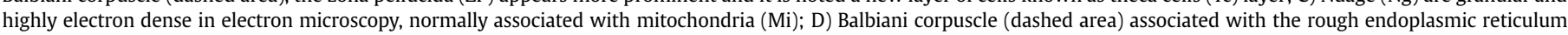

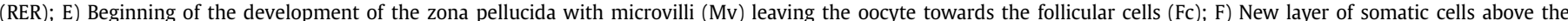

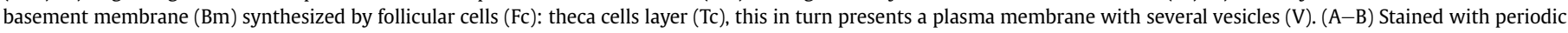
acid - Schiff's reactive + iron hematoxylin + metanil yellow; $(\mathrm{C}-\mathrm{F})$ Transmission Electron Microscopy. 

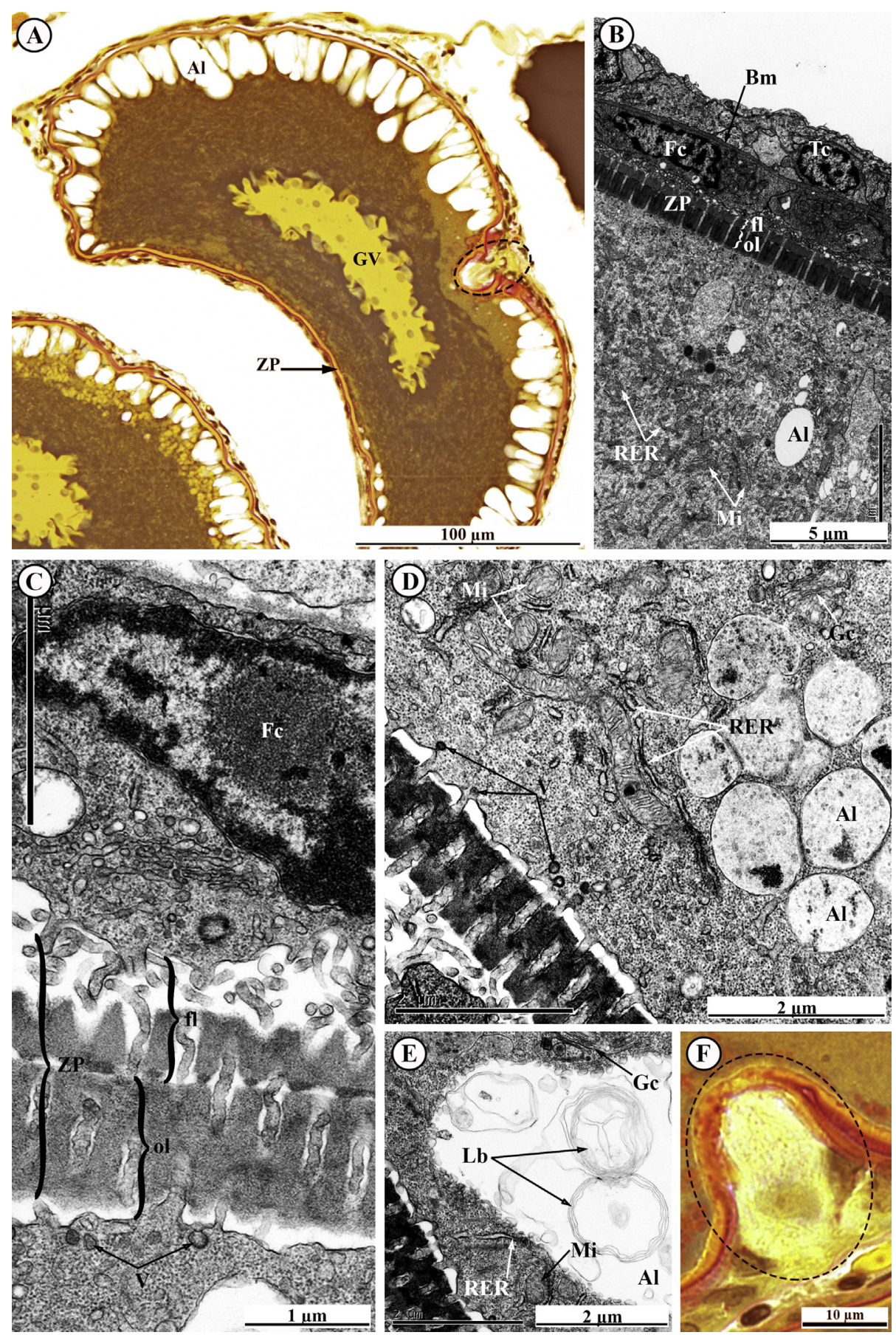

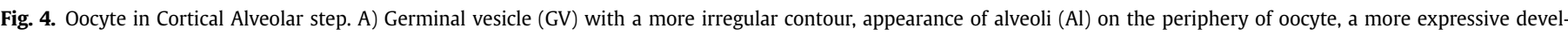

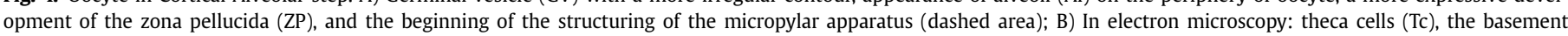

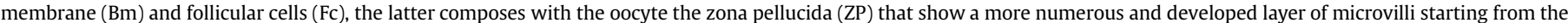

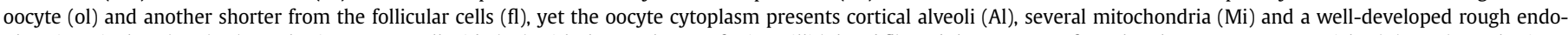

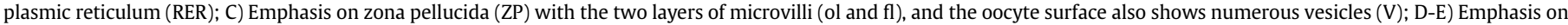

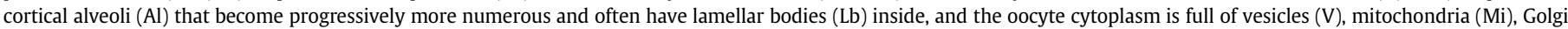

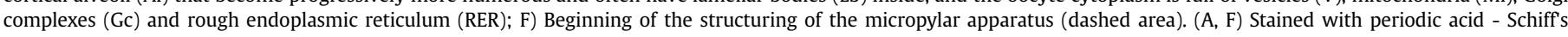
reactive + iron hematoxylin + metanil yellow; (B-E) Transmission Electron Microscopy.

several smaller vessels are then found to be distributed through the tissue (Fig. 7D). It is important to note that this vessel distribution pattern (large associated vessels and smaller vessels distributed in the tissue) and the connective tissue distribution pattern do not seem to vary as the ovaries develop.

\subsection{Characteristics of the reproductive cycle}

In the oogonia, nuclear immunostaining against PCNA was evident, and the pre-follicular cells were stained as well (Fig. 8A). There was significant variation in the proportion of immunostained oogonia throughout the year $(\mathrm{F}=4.649$; $\mathrm{P}<0.001$; Fig. $8 \mathrm{~B})$. The 

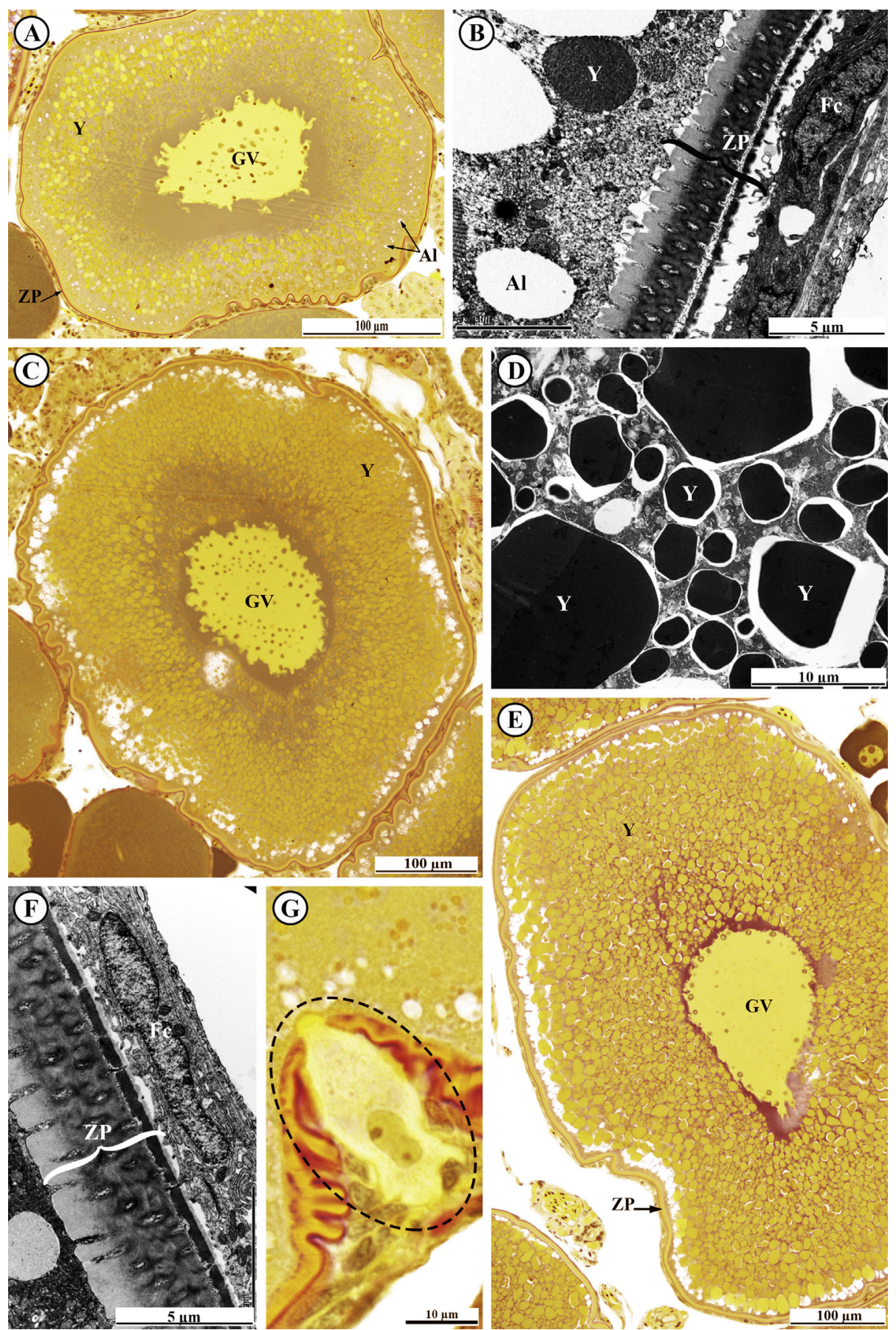

Fig. 5. Oocyte in secondary growth. A-B) "Early": yolk vesicles (Y) are seen as small spherical vesicles scattered below the cortical alveoli (Al), germinal vesicle (GV) with highly irregular contour, the zona pellucida (ZP) is thicker as the microvilli of the oocyte and follicular cells (Fc) elongate; C-D) "Late": yolk vesicles (Y) with a maximum diameter, although it is possible to observe vesicles with different sizes; E) "Full-grown": oocyte with cytoplasm filled with yolk vesicles (Y); F) Zona pellucida (ZP) fully developed; G) Micropylar apparatus (dashed area) completely formed. (A, C, E, G) Stained with periodic acid - Schiff's reactive + iron hematoxylin + metanil yellow; (B, D, F) Transmission Electron Microscopy.

specimens collected prior to the reproductive season (March to September) exhibited a lower proportion of immunostained oogonia. Meanwhile, regardless of the extent of reproductive management, specimens collected during the reproductive season (October to February) exhibited a higher proportion of immunostained oogonia, despite some reduction in the total number of oogonia starting in December.

This same variation in the number of oogonia was found in the quantitative analysis of germ cells (Fig. 9): prior to the reproductive season, the ovaries exhibited few oogonia, abundant pre-vitellogenic oocytes, some vitellogenic oocytes, the absence of postovulatory complexes, and some atresia. The specimens collected in the reproductive season exhibited several changes in the proportions of these structures, even when reproductive management techniques were not applied. The group in which reproduction was not managed exhibited ovaries with many oogonia, an abundance 

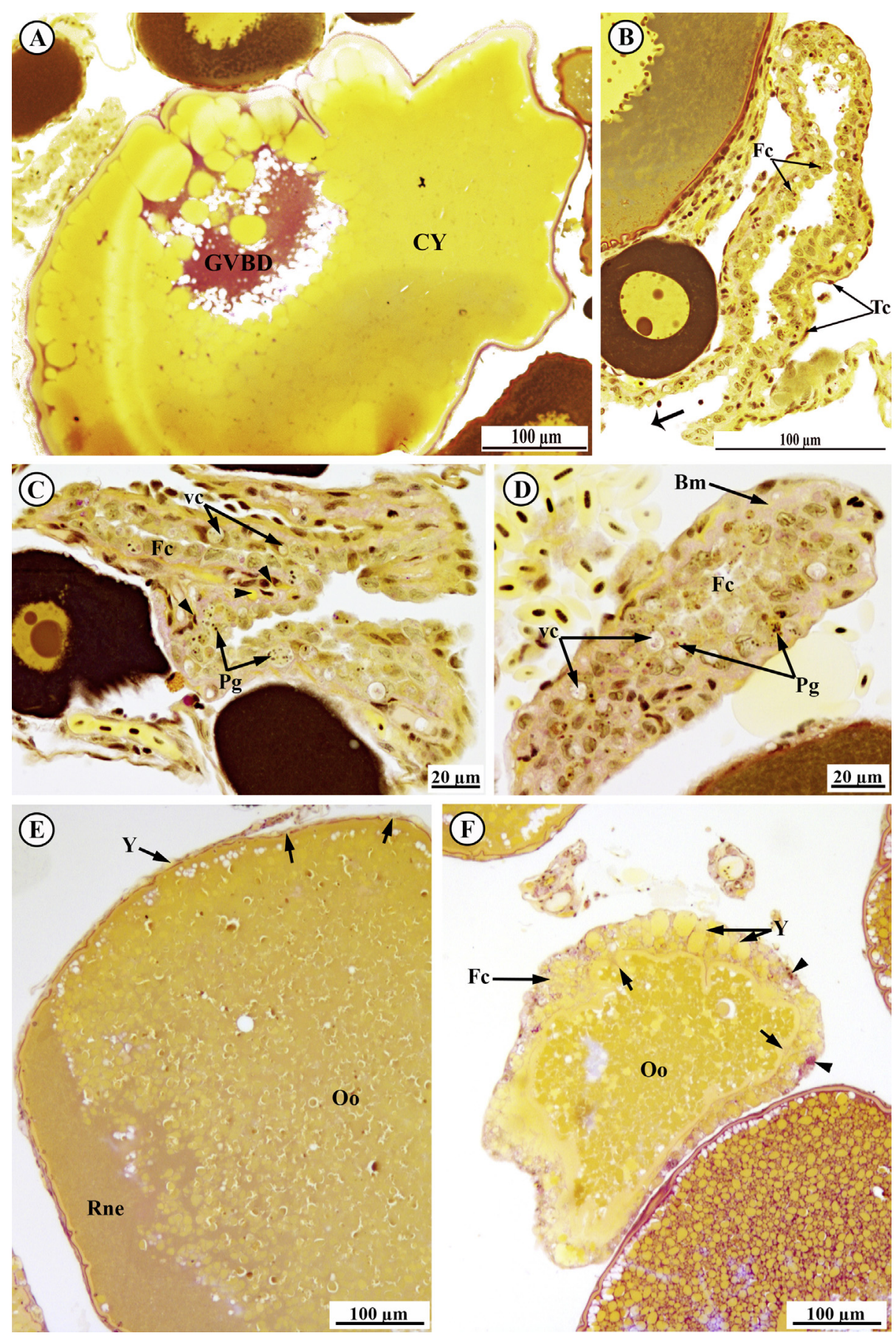

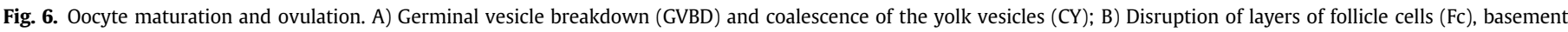

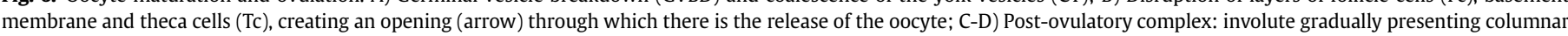

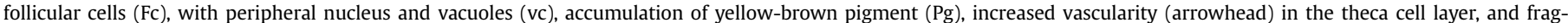

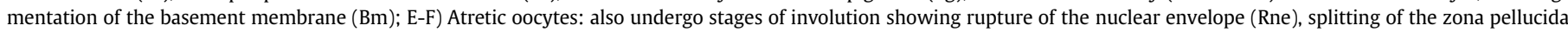

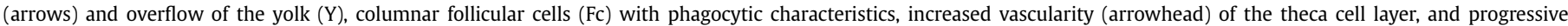
reduction in oocyte volume (Oo). All figures were stained with periodic acid - Schiff's reactive + iron hematoxylin + metanil yellow.

of pre-vitellogenic oocytes and vitellogenic oocytes, few postovulatory complexes, and some atresia. When reproduction was managed, the specimens exhibited increased numbers of oogonia and pre-vitellogenic oocytes, few vitellogenic oocytes, many postovulatory complexes, and some atresia.

These cell proportions corroborate the results found in the GSR ratio analysis. The GSR varied throughout the period of the study $(H=151.827 ; \mathrm{P}<0.001)$. This variation can be seen in Fig. 10 , in which points at the same height represent values that are statistically equal according to the paired Wilcoxon test. We observed that the ovaries gradually increased in weight, thus increasing gonadosomatic ratio. Heavier ovaries, which are those with more advanced development and with larger cells, began appearing at the beginning of the reproductive season (September) in specimens in which reproduction was not managed. The lowest GSR values, which represented the lighter ovaries (those with cells in the 

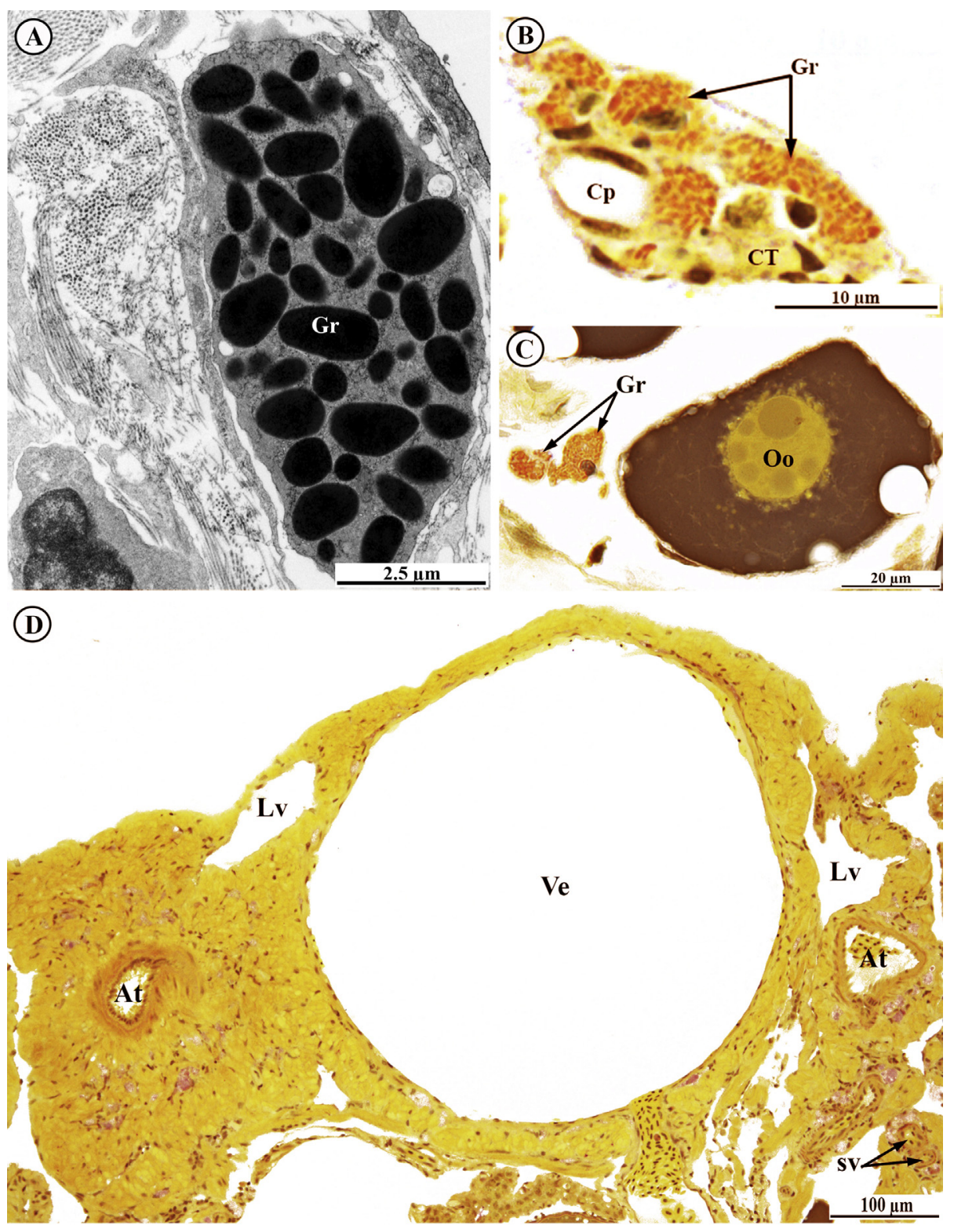

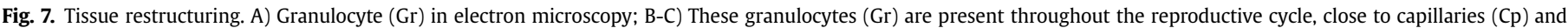

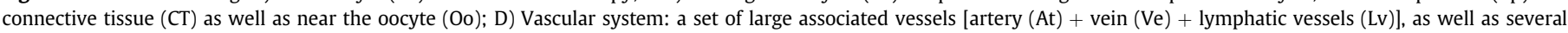

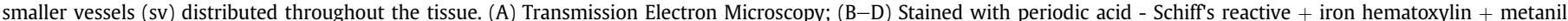
yellow.

primary stage of development or those which occurred after spawning), were found in specimens outside the reproductive season (May to July) and in specimens in the reproductive season in which reproductive management techniques were applied.

In light of the reproductive characteristics observed, one can infer that this species was in a "spawning capable" phase all year, whether in its standard reproductive period or beyond, and even after reproductive management was put into practice. When reproduction was managed, the specimens presented many postovulatory complexes and oocytes in primary growth in their ovaries, and vitellogenic oocytes were still present, including oocytes in the full-grown step.

\section{Discussion}

In the reproductive analysis, we found that $A$. altiparanae ovaries are paired and ovoid organs, as has been described for other species of this genus $[1,24,25]$. However, two aspects seem to vary throughout development not only in relation to the reproductive season, but also between Astyanax species: the vascularization pattern and the color of ovaries.

In this study, the ovaries were found to be highly vascularized throughout the year, particularly among specimens that had spawned. In a study conducted with Astyanax scabripinnis and A. paranae (=A. scabripinnis paranae) specimens, ovaries vascularization was slight during development and increased in intensity when the fish matured and spawned, with hemorrhagic characteristics after spawning [26,27]. Notwithstanding the lack of A. altiparanae ovaries in development, our findings are consistent with the descriptions of the other species from the genus.

Ovaries color in this study changed from brown to gray and finally to red, changes which were consistent with changes in 

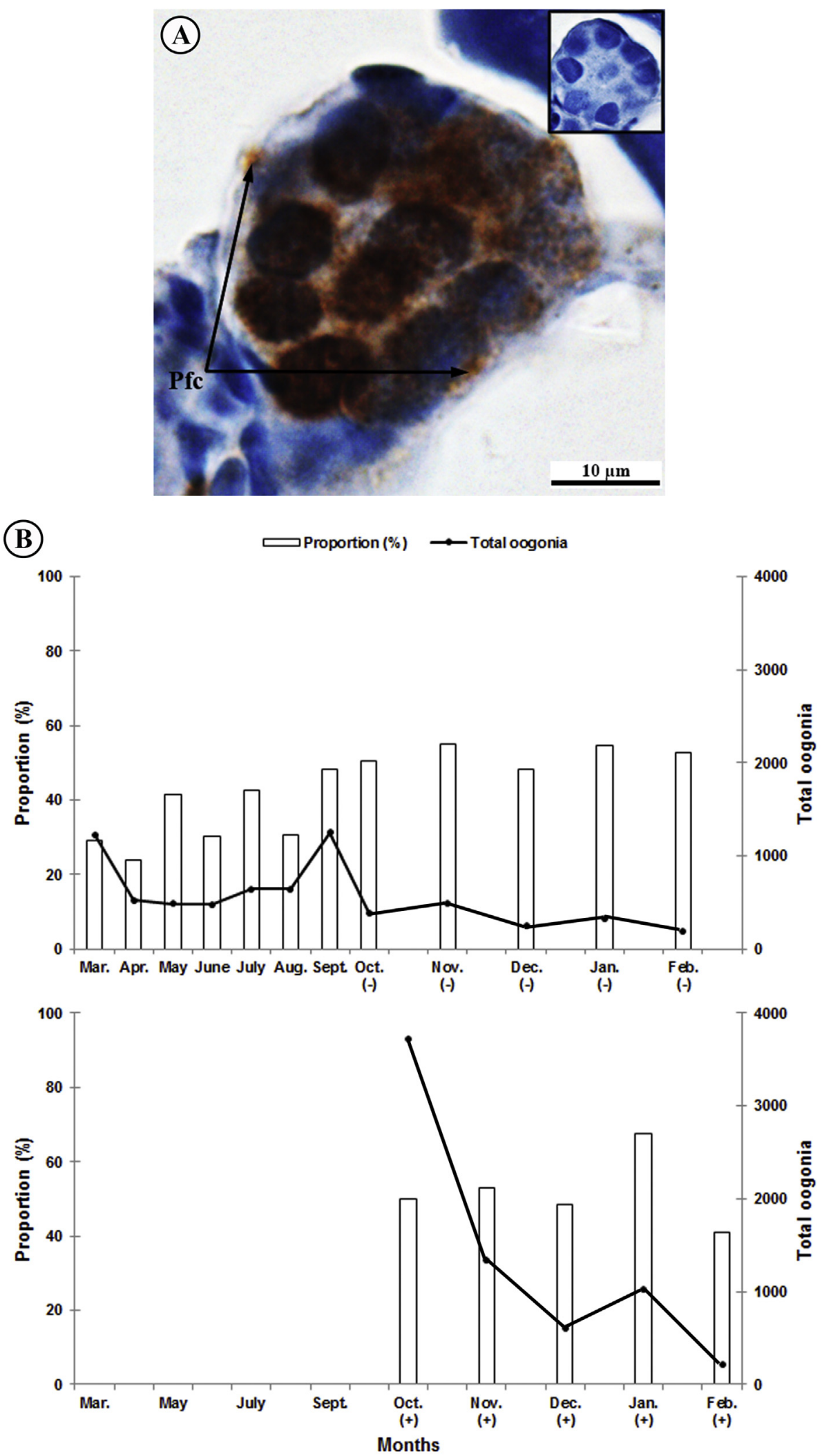

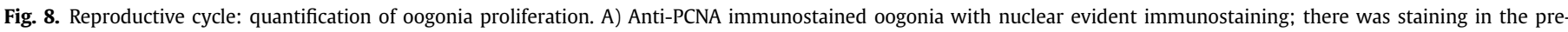

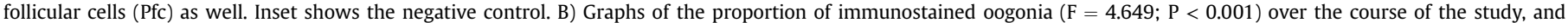
the variation in the total number of oogonia, separated by groups in which reproduction was managed $(+)$ and was not managed $(-)$.

weight. Veregue and Orsi [26] described that $A$. paranae ovaries were orange to greyish-white when mature, brown-green during the spawning process, and reddish-brown after spawning. This variation in ovaries color may be species-specific, or may even be due to differences in feeding habits and habitat [28]. It is also worth mentioning that the ovaries colors seen throughout development 

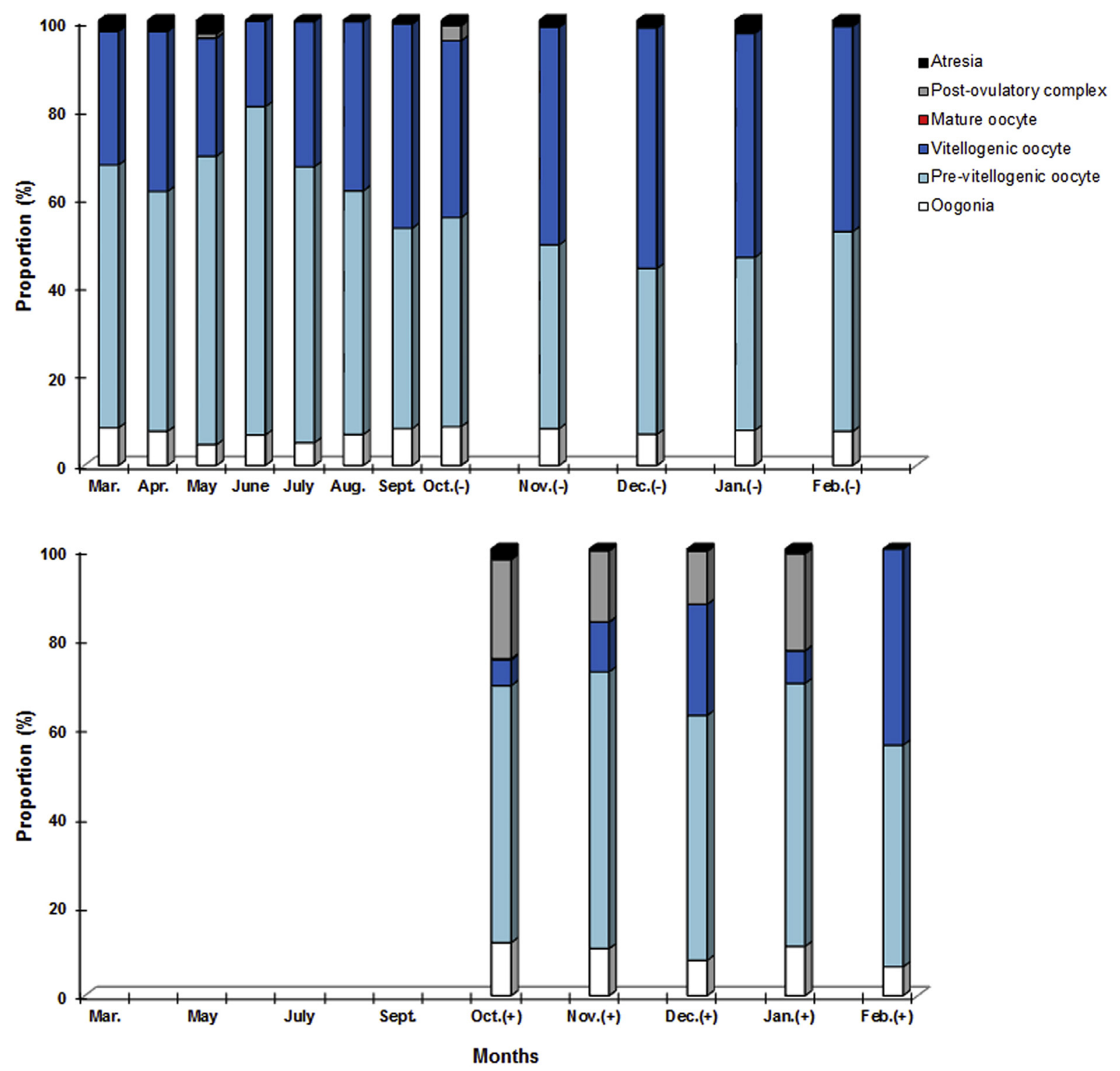

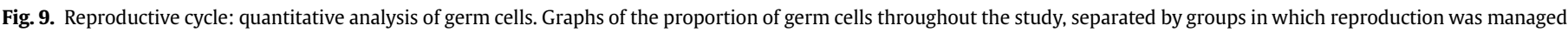
$(+)$ and was not managed $(-)$.

and the variations between species may be influenced by the person analyzing the parameter, as the interpretation of ovarian color may be very subjective. The reddish color after spawning may be caused by hemorrhagic processes that result from this act or by the large presence of vessels contrasted by the decreasing in the number of germ cells. Still, it is important to note that no other study has correlated ovaries color and weight, nor the frequency distribution of these colors over the sampling period. Both sets of data enable a more direct correlation with the GSR and may be relevant when applied to fish farms, since this information allows the producer to determine the fish's phase of ovarian development.

When the microscopic features were considered, the ovaries were found to be classified as cystovarian, as summarized in a description by Grier et al. [29]. The germ cells are arranged along the entire lamella and occur in various stages of development. This development of oogonia into mature oocytes seems to be consistent among different teleost species [22], though this study provides many new details on Astyanax species. Important details include: (1) the presence of the annulate lamellae in oogonia, they are cytoplasmic pores whose function has not yet been established, though it is known that they do not serve any intracellular transport purposes [30]; and, (2) the development of the zona pellucida from oocytes in the one-nucleolus step, starting with microvilli of the oocyte toward the follicular cells until they are completely formed in full-grown oocytes. The zona pellucida is a complex structure consisting of an extra-oocyte matrix within which there is microvilli development between the oocyte and the follicular cells; the production of these microvilli supports the development of the heterologous gap junctions required for physiological communication during oocyte maturation [31,32].

Another important microscopic characteristic is the development of the micropylar apparatus. In this study, the micropyle was found in oocytes in the cortical alveolar step, despite being more frequent in oocytes in secondary growth. The same was observed in A. scabripinnis [24,33], while in Brycon orbignyanus and Salminus hilarii (other characids), the micropylar apparatus was observed 


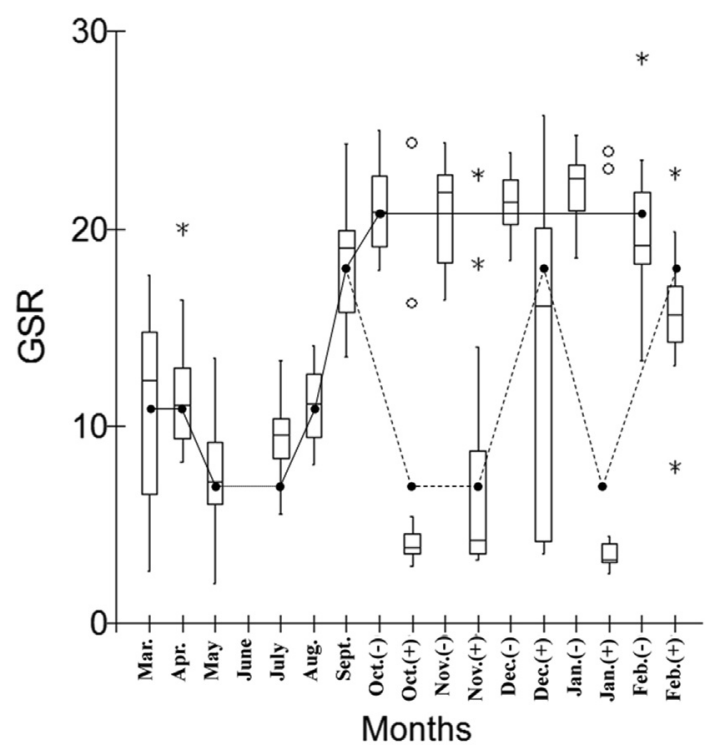

Fig. 10. Reproductive cycle: analysis of the gonadosomatic ratio (GSR). Graph with the variation in the gonadosomatic ratio (GSR) over the course of the study ( $\mathrm{H}=151.827$; $\mathrm{P}<0.001$ ); points at the same height represent values that are statistically equal, including groups in which reproduction was managed $(+)$ and was not managed (-).

only in oocytes in secondary growth [28,34]. The micropylar apparatus is a funnel-shaped structure through which fertilization occurs in fish; a single spermatozoa passes through the micropyle, after which it closes and prevents polyspermy [32].

The characterization of germ cell morphology at different stages of development was considered in the analysis of their distribution and frequency in the ovaries. This information allowed us to estimate the reproductive period and the type of spawning employed by the species. Given the proliferation rate, the quantitative analysis of the ovaries, and the gonadosomatic ratio over the course of the study, we found that $A$. altiparanae has a long spawning period with reproductive peak from October to February. The asynchronous development of oocytes, with post-ovulatory complexes and vitellogenic oocytes present at the same time, indicates that the species has multiple spawning events. The same reproductive period was observed by Viana et al. [19] in a study on A. altiparanae, as well as in studies on A. scabripinnis $[24,27,33]$ and $A$. paranae [26,35]. The reproductive period of $A$. henseli was found to be shorter - from August to December [36], and A. bimaculatus exhibited continuous reproductive activity throughout the year, though with reduced gonadal activity from May to July [37].

As reported in the literature on Astyanax species, there is some variation in the duration of the reproductive period [36]. However, similar to the current findings, most studies on this genus report seasonal reproduction in spring and summer in the Southern Hemisphere (from September to March), with durations ranging from four to six months $[19,27,33,38-42]$. Similarly, it seems that there is no uniformity in the type of spawning among Astyanax species. A. altiparanae was found herein to engage in multiple spawning, similar to A. bimaculatus [37,39], A. scabripinnis $[24,27,33,43]$, and $A$. fasciatus [44]. However, other studies have found cases of total spawning among $A$. schubarti [38], A. fasciatus [38,45], A. henseli [36], and A. bimaculatus [38,46].

It is important to note, however, that these fish seem to be able to switch from total spawning to multiple spawning (and vice versa) as a result of physiological or environmental changes. This shift can lead to various spawning types among different populations or in different periods of time. Garutti [47] studied
A. bimaculatus ( $=$ A. altiparanae) in different environments of a watercourse in the Paraná River basin and found evidence of different types of spawning in this unique species, with multiple spawning on the upper and middle reaches of the river and total spawning in the estuary regions.

Interestingly, a previous study by members of our research group [48] found that A. altiparanae males also appear to exhibit multiple spermiation. A. altiparanae testes were found to possess different areas during different phases of the annual reproductive cycle, and the maintenance of the testicular regions throughout the cycle seems to enable the males to produce sperm and have reserves of its gamete inside the testes almost all year. This allows this species to provide multiple releases of sperm, an ability which is likely to be in accordance with more favorable environmental conditions [48].

Variations in A. altiparanae spawning and spermiation periods and the species' ability to reproduce in lentic environments, including in reproductive management schemes, suggest that this species has the ability to respond quickly to environmental changes and exhibits high reproductive flexibility [49]. Taken together, all of these characteristics reinforce the important role that this species can play in fish farming. The fact that tetra specimens have male and female gonads in the "spawning capable" phase throughout the year indicates the possibility of performing reproductive management at other times, thus increasing the availability of fish-seed and juveniles in fish farming.

\section{Conclusions}

Studies that present detailed information on reproductive characteristics, including macroscopic to the cellular analyses associated with its temporal distributions, promote a greater understanding of species biology. This scientific development establishes a solid basis for new reproductive experiments and technologies, especially in terms of the applications to species that are as important to fish farming as Astyanax altiparanae is in Brazil.

\section{Acknowledgments}

This work was supported by São Paulo Research Foundation, or FAPESP (grant numbers \#2011/09567-8, \#2012/24434-7, and \#2014/23451-0). The authors thank C.A.M. Rigonati and G.F. Lima for the technical assistance when processing the samples; they also thank the São Paulo Energy Company of Paraibuna for providing some of the specimens and for aiding in reproductive management process conducted at their Hydrobiology and Aquaculture Station. The authors are also grateful to V.E. Arana-Chavez for providing the transmission electron microscope and to J.F. Dias and E. Bevilacqua for their review of and suggestions for this manuscript.

\section{References}

[1] Mazzoni R, Mendonça RS, Caramaschi EP. Reproductive biology of Astyanax janeiroensis (Osteichthyes, Characidae) from the Ubatiba river, Maricá, RJ, Brazil. Braz J Biol 2005;65:643-9.

[2] Wallace RA, Sellman K. Cellular and dynamic aspects of oocyte grownth in teleosts. Am Zool 1981;21:325-43.

[3] Vazzoler AEAM. Biologia da reprodução de peixes teleósteos: teoria e prática. Maringá: Eduem; 1996.

[4] Kjesbu OS, Hunter JR, Witthames PR. Report of the working group on modern approaches to assess maturity and fecundity of warm- and cold-water fish and squids, vol. 12. Norway: Institute of Marine Research; 2003.

[5] Honji RM, Vaz-dos-Santos AM, Rossi-Wongtschowski CLDB. Identification of the stages of ovarian maturation of the argentine hake Merluccius hubbsi Marini, 1933 (Teleostei: Merluciidae): advantages and disadvantages of the use of the macroscopic and microscopic scales. Neotrop Ichthyol 2006;4: 329-37.

[6] Tyler CR, Sumpter JP. Oocyte growth and development in teleosts. Rev Fish Biol Fish 1996;6(3):287-318. 
[7] Lowerre-Barbieri SK, Brown-Peterson NJ, Murua H, Tomkiewicz J, Wyanski DM, Saborido-Rey F. Emerging issues and methodological advances in fisheries reproductive biology. Mar Coast Fish 2011;3(1):32-51.

[8] Krysko DV, Diez-Fraile A, Criel G, Svistunov AA, Vandenabeele P, D'Herde K. Life and death of female gametes during oogenesis and folliculogenesis. Apoptosis Int J Program Cell death 2008;13(9):1065-87.

[9] Tokarz RR. Oogonial proliferation, oogenesis and folliculogenesis in nonmammalian vertebrates. In: Jones RE, editor. The vertebrate ovary: comparative biology and evolution. New York: Plenum Press; 1978. p. 145-79.

[10] Jalabert B. Particularities of reproduction and oogenesis in teleost fish compared to mammals. Reprod Nutr Dev 2005 May-Jun;45(3):261-79.

[11] Nakamura S, Kobayashi K, Nishimura T, Tanaka M. Ovarian germline stem cells in the teleost fish, medaka (Oryzias latipes). Int J Biol Sci 2011:7:403-9.

[12] Quagio-Grassiotto I, Grier H, Mazzoni TS, Nóbrega RH, Amorim JPA. Activity of the ovarian germinal epithelium in the freshwater catfish, Pimelodus maculatus (Teleostei: Ostariophysi: Siluriformes): germline cysts, follicle formation and oocyte development. J Morphol 2011;272:1290-306.

[13] Billard R. The reproductive cycle of male and female brown trout (Salmo trutta fario): a quantitative study. Reprod Nutr Dev 1987;27:29-44.

[14] Mylonas CC, Zohar Y. Promoting oocyte maturation, ovulation and spawning in farmed fish. In: Babin PJ, Cerdà J, Lubzens E, editors. The fish oocyte: from basic studies to biotechnological applications. Netherlands: Springer; 2007 p. 437-74.

[15] Nelson JS, Grande TC, Wilson MVH. Fishes of the world. fifth ed. New Jersey: Wiley; 2016.

[16] Porto-Foresti F, Castilho-Almeida RB, Foresti F. Biologia e criação do lambarido-rabo-amarelo (Astyanax altiparanae). In: Baldisseroto B, Gomes LC, editors. Espécies Nativas para Piscicultura no Brasil, vol. 2. Santa Maria: Editora UFSM; 2005. p. $101-15$.

[17] Garutti V, Britski HA. Descrição de espécie nova de Astyanax (Teleostei: Characidae) da bacia do alto rio Paraná e considerações sobre as demais espécies do gênero na bacia. Comun Mus Ciênc Tecnol PUCRS 2000;13:65-88.

[18] Gonçalves LU, Parisi G, Bonelli A, Sussel FR, Viegas EMM. The fatty acid compositions of total, neutral and polar lipids in wild and farmed lambari (Astyanax altiparanae) (Garutti \& Britski, 2000) broodstock. Aquacult Res 2014;45:195-203.

[19] Viana LF, Tondato KK, Súarez YR, Lima-Júnior SE. Influence of environmenta integrity on the reproductive biology of Astyanax altiparanae Garutti \& Britski, 2000 in the Ivinhema river basin. Acta Sci Biol Sci 2014;36:165-73.

[20] Chehade C, Cassel M, Borella MI. Induced reproduction in a migratory teleost species by water level drawdown. Neotropical Ichthyol 2015:13(1):205-12.

[21] Quintero-Hunter I, Grier H, Muscato M. Enhancement of histological detail using metanil yellow as counterstain in periodic acid Schiff's hematoxylin staining of glycol methacrylate tissue sections. Biotech Histochem 1991;66(4): 169-72.

[22] Grier HJ. Development of the follicle complex and oocyte staging in red drum, Sciaenops ocellatus Linnaeus, 1776 (Perciformes, Sciaenidae). J Morpho 2012:273:801-29.

[23] Brown-Peterson NJ, Wyanski DM, Saborido-Rey F, Macewicz BJ, LowerreBarbieri SK. A standardized terminology for describing reproductive development in fishes. Mar Coast Fish 2011:3(1):52-70.

[24] Melo FCSA, Maldonado IRSC, Benjamin LA, Matta SLP. Biologia reprodutiva de fêmeas de lambari-prata (Astyanax scabripinnis) (Characidae, Tetragonopterinae) em tanques de piscicultura. Rev Ceres 2005;52:811-29.

[25] Rodrigues LP, Querol E, Braccini MC. Descrição morfo-histológica do ovário de Acestrorhynchus pantaneiro (Menezes, 1992) (Teleostei, Characidae), em seus diferentes estágios de desenvolvimento na bacia do rio Uruguai médio, Uruguaiana, RS. Biodivers Pampeana 2005;3:11-8.

[26] Veregue AML, Orsi ML. Biologia reprodutiva de Astyanax scabripinnis paranae (Eigenmann) (Ostheichthyes, Characidae), do ribeirão das Marrecas, bacia do rio Tibagi, Paraná. Rev Bras Zool 2003;20:97-105.

[27] Veloso-Júnior VC, Guimarães-Cruz RJ, Barros MDM, Barata RSL, Santos JE. Reproduction of the lambari Astyanax scabripinnis (Jenyns, 1842) (Pisces: Characidae) in a small stream in southeastern Brazil. J Appl Ichthyol 2009;25: 314-20.

[28] Honji RM, Narcizo AM, Borella MI, Romagosa E, Moreira RG. Patterns of oocyte development in natural habitat and captive Salminus hilarii Valenciennes,
1850 (Teleostei: Characidae). Fish Physiol Biochem 2009;35:109-23.

[29] Grier HJ, Uribe MC, Parenti LR. Germinal epithelium, folliculogenesis, and postovulatory follicles in ovaries of rainbow trout, Oncorhynchus mykiss (Walbaum, 1792) (Teleostei, Protacanthopterygii, Salmoniformes). J Morphol 2007;268:293-310.

[30] Kessel RG. The annulate lamellae-from obscurity to spotlight. Electron Microsc Rev 1989;2(2):257-348.

[31] Andrade RF, Bazzoli N, Rizzo E, Sato Y. Continuous gametogenesis in the neotropical freshwater teleost, Bryconops affinis (Pisces: Characidae). Tissue Cell 2001;33:524-32.

[32] Lubzens E, Young G, Bobe J, Cerdà J. Oogenesis in teleosts: how eggs are formed. General Comp Endocrinol 2010;165(3):367-89.

[33] Pereira Filho HP, Andrade DR, Tonini WCT, Vidal Jr MV. Biologia reprodutiva de fêmeas de lambari-prata, Astyanax scabripinnis Jenyns, 1842 (Characidae; Tetragonopterinae; Teleostei) em condições de cativeiro. Ci Anim Bras 2011;12:626-34.

[34] Ganeco LN, Nakaghi LSO, Urbinati EC, Dumont Neto R, Vasques LH. Análise morfológica do desenvolvimento ovocitário de piracanjuba, Brycon orbignyamus, durante o ciclo reprodutivo. Bol Inst Pesca 2001;27:131-8.

[35] Abelha MCF, Goulart E. Population structure, condition factor and reproductive period of Astyanax paranae (Eigenmann, 1914) (Osteichthyes: Characidae) in a small and old brazilian reservoir. Braz Arch Biol Technol 2008;51:503-12.

[36] Dala-Corte RB, Azevedo MA. Biologia reprodutiva de Astyanax henseli (Teleostei, Characidae) do curso superior do rio dos Sinos, RS, Brasil. Iheringia, Sér Zool 2010;100:259-66.

[37] Barreto BP, Ratton TF, Ricardo MCP, Alves CBM, Vono V, Rizzo E, et al. Biologia reprodutiva do lambari Astyanax bimaculatus (Pisces, Characidae) no rio do Carmo, bacia do rio Grande, São Paulo. BIOS 1998;6:121-30.

[38] Fecundidade Nomura H. maturação sexual e índice gonadossomático de lambaris do gênero Astyanax Baird e Girard, 1854 (Osteichthyes, Characidae), relacionados com fatores ambientais. Rev Bras Biol 1975;35:775-98.

[39] Agostinho CA, Molinari SL, Agostinho AA, Verani JR. Ciclo reprodutivo e primeira maturação sexual de fêmeas do lambari Astyanax bimaculatus (Osteichthyes, Characidae) do rio Ivaí, Estado do Paraná. Rev Bras Biol $1984 ; 44: 31-6$

[40] Barbieri GM, Hartz SM, Verani JR. O fator de condição e índice hepatossomático como indicadores do período de desova de Astyanax fasciatus da represa do Lobo, São Paulo (Osteichtyes, Characidae). Iheringia, Sér Zool 1996;81:97-100.

[41] Braga FMS. Reprodução de peixes (Osteichthyes) em afluentes do reservatório de Volta Grande, Rio Grande, sudeste do Brasil. Iheringia, Sér Zool 2001;91: $67-74$.

[42] Abilhoa V. Aspectos da história natural de Astyanax scabripinnis Jenyns (Teleostei, Characidae) em um riacho de floresta com araucária no sul do Brasil. Rev Bras Zool 2007;24:997-1005.

[43] Barbieri GM. Biologia de Astyanax scabripinnis paranae (Characiformes, Characidade) do ribeirão do Fazzari. São Carlos. Estado de São Paulo. II. Aspectos quantitativos da reprodução. Rev Bras Biol 1992:52:589-96.

[44] Carvalho PA, Paschoalini AL, Santos GB, Rizzo E, Bazzoli N. Reproductive biology of Astyanax fasciatus (Pisces: Characiformes) in a reservoir in southeastern Brazil. J Appl Ichthyol 2009;25:306-13.

[45] Gurgel HCB. Estrutura populacional e época de reprodução de Astyanax fasciatus (Cuvier) (Characidae, Tetragonopterinae) do Rio Ceará Mirim, Poço Branco, Rio Grande do Norte, Brasil. Rev Bras Zool 2004;21:131-5.

[46] Santos GB, Barros LNV, Menezes MU. Fecundity of the Astyanax bimaculatus (Reinhardt, 1874) (teleostei, Characidae) from upper rio São Francisco basin, Brasil. Arq Bras Med Vet Zootec 1996;48:101-8.

[47] Garutti V. Contribution to the knowledge of the reproduction of Astyanax bimaculatus (Ostariophysi, Characidae), in waters of the Paraná River basin. Rev Bras Biol 1989;49:489-95.

[48] Costa FG, Adolfi MC, Gomes CC, Jesus LWO, Batlouni SR, Borella MI. Testes of Astyanax altiparanae: the Sertoli cell functions in a semicystic spermatogenesis. Micron 2014;61:20-7.

[49] Dias RM, Baially D, Antônio RR, Suzuki HI, Agostinho AA. Colonization of the corumbá reservoir (Corumbá river, Paraná River basin, Goiás state, Brazil) by the "lambari" Astyanax altiparanae (tetragonopterinae; Characidae). Braz Arch Biol Technol 2005;48:467-76. 